\title{
Institutional Problems Diminishing Quality of Secondary Education in Sindh: Teachers' Sentiments
}

\author{
Shahid Saleem Arain', Muhammad Arshad ${ }^{2 *}$ and Gulzar Ahmed ${ }^{3}$ \\ 'Department of Education, University of Sufisim and Modern Sciences, Bhittshah, Pakistan; \\ dr.shahid.arain.usms@gmail.com \\ 2Department of Education, The University of Lahore, Pakistan; marshadzakki@gmail.com \\ 32Department of Education, Pakpattan Campus, The University of Lahore, Pakistan; dr.gulzar2016@gmail.com
}

\begin{abstract}
Objective: The main purpose of the study was to explore the institutional problems that diminish the quality of secondary education institutions in Pakistan. Methodology: It was a quantitative survey of SE system in Sindh province. The target population of the study comprised of 711 High School Teachers (HSTs) working in public secondary schools of SED Sindh, deployed at Mirpurkhas district and the sample of 126 HSTs from all the 85 secondary schools of the district was considered sufficient. The research tool used to collect data was a questionnaire constructed on 5-point Likert scale consisting of two parts. The part A consisted of 12 closed ended questions and part B had an open question. The data was collected by personal visits of the schools. Descriptive and inferential statistics in terms of percentages and means scores was used to analyze and interpret the data. Findings: The lacks of SE, found after the analysis of the data include unskilful teachers, dissatisfaction of teachers because of media trail and non-professional behaviour of HMs, general and academic facilities, teachers' gossip, unsuitable curricula, low status of primary education, unskilful HMs and late promotions of HSTs. Improvements: The study recommends a short training course for teachers, appreciation of the work, provision of general and academic facilities, avoiding gossips by dispersal, arranging educational environment, converting curricula in easy format, timely promotions of the HSTs, improving quality of primary education, active management and professional training to HMs for better curricular and administrative affairs.
\end{abstract}

Keywords: Academic Facilities, Institutional Problems, Quality Education, Secondary Education

\section{Introduction}

Education is highly significant for nations' awareness, economy as well as human development. It provides training and skills to make them useful to society. The productivity of an education system proves when skilled, competent and competing individuals are produced. Every nation has a great desire to enhance the quantity and quality of education to compete the modern world. Those nations made progresses which have perfect education system $\stackrel{1}{ }$. Pakistan is the sixth largest country with the population of 22 billion 2 . Education system has seen multiple changes: many education policies were given from the birth of Pakistan, but mostly these policies disagreed with each other in mode of operation. These policies were partially implemented and lost their theme. The politicians claiming to provide quality education used them for their political gains and gave them desired bent ${ }^{3}$. The milestone of universal and quality education remained unachieved. The centralized education system and unwise political behaviour also affected the system that some areas made such developments in education and infrastructure and other remained ignored. Pakistan, after more than seventy years of independence has reached to $58 \%$ literacy rate ${ }^{4}$, which was only $13 \%$ at the time of its birth. Pakistan is a developing country but the situation is not equal for all the country. Some areas

*Author for correspondence 
are thickly populated with modern facilities and others having scattered population with less facilities. Pakistan has two tier problems in education i-e quantity and quality. Firstly the literacy rate of Pakistan is relatively low and adult literacy rate is $72 \%$ but the enrolment rate ${ }^{5}$ in primary schools is $91 \%$. Secondly, the quality of education is comparatively low. Therefore, Pakistan has to raise the enrolment at schools as well as improve the quality of education. The dropout rate in Pakistan is very high that after passing primary education only 59\% students are enrolled in lower secondary schools, while $98 \%$ of them are enrolled to high schools.

Secondary Education (SE) is as important as primary level education because it has to continue the students for further education giving specific direction. It not only strengthens the roots of education but also plays an instrumental role in shaping and directing a child towards a bright future, providing comprehensive competencies and variety of skills ${ }^{6}$. The SE was never given proper importance and the bad impact of primary education also damaged its image. The problems related with quality, quantity and administration are reported by various researches. The financial resources are also a big problem in education sector; the developing countries spend very little on education. Pakistan aimed to allocate 7\% of GDP on education by the year 2015 in vision 2030 but could not succeed, and presently spends only $2.2 \%$ of GDP on education ${ }^{?}$.

Education is now a provincial subject after $18^{\text {th }}$ amendment in constitution of Islamic Republic of Pakistan. Sindh province has more than 500 million populations which makes it the second largest province of Pakistan.

School Education Department (SED) has been facing issues and problems regarding quality process, output and administration. The SE in Sindh ${ }^{8}$ runs with 16,882 middle and 12,732 high schools with 4.039 million middle school students and 2.227 million that of high schools in public sector. A large number of schools lack basic facilities, teachers and proper officers. SED has computerised the system through SEMIS and PIFRA which helped in controlling financial matters and monitoring the activities of the schools. The biometric attendance system has controlled absconding and ghost teachers but still quality process gaps in the form of institutional problems are observed. Hence, this study will investigate the reason behind the problem. The SE system will be analyzed to diagnose the factors affecting the quality of input.

\subsection{Statement of the Problem}

The aim of the study was to investigate the institutional problems related with teachers and onsite management diminishing the quality process at public sector SE system in Pakistan with main focus on the Province of Sindh.

\subsection{Objectives of the Study}

The prime purpose of the study was to explore the institutional factors declining quality of input in SE system of Pakistan. It aims to study the system weakness in context of teachers' sentiments. Hence, the main objectives of this study are:

1. To explore the factors diminishing the input quality of education related with teachers.

2. To explore the factors declining the quality of education related with onsite management.

3. To give solutions of the problems related with teachers and management.

\subsection{Research Questions}

The objectives of the study led to formulate the following research questions:

1. What are the factors faced by teachers that decline the input quality of secondary education?

2. What are the factors posed by the onsite management that decline the quality process of secondary education in Sindh?

3. What is the solution of the problems related with teachers and posed by the onsite management?

\section{Review of Related Literature}

SE is criticized in respect of quality process, facilities and managerial problems. SED has been facing many challenges related with teachers, quality, quantity and management. The studies conducted by some researchers in this regard are as under;

Teacher's contribution ${ }^{9}$ for quality education was necessary and administration was responsible for teachers' job satisfaction leading to good performance through administrative support and working condition.

The problems ${ }^{10}$ of education in Pakistan as lack of uniformity in educational structure, underactive education, outdated curricula, and lack of professional development 
in teachers, alarming drop out, poor supervision, internal and external influences and lack of funds.

Major issues $\frac{11}{11}$ of education sector in Pakistan as less women involvement in education, substandard curricula, child labour, less chances of teacher education, gender discrimination, less research work and lack of technical skills in teachers. The schools ${ }^{12}$ having problems with leadership were reported to have slower implementation of school reforms. The quality of the education highly depends upon the efficiency of school head.

The work load $\frac{13}{}$, students' behaviour, autocratic treatment of HMs, teaching skills, academic facilities as problems related with teachers' satisfaction and performance. The lack $\frac{14}{4}$ of academic facilities, influenced transfers, accommodation facility, over burden, autocratic behaviour of management, teacher politics, and teachers working relationship affected the quality of education.

The quality of education $\frac{15}{}$ depended equally upon teachers, curricula and facilities without missing any of them. All the three elements are interrelated and required quality. Sindh education Reform Support Program ${ }^{16}$ (SERP) has four main pillars i-e improving fiscal sustainability, education sector management, access to quality schooling and, quality of teaching and learning. The causes of decline of education in Pakistan ${ }^{17}$ as low enrolment rate, high dropout, multidimensional education system, political interference, substandard curricula, rapid population growth, sub-standard teachers training and evaluation system.

The poor quality of teachers responsible for low quality of education $\frac{18}{}$ and advised that quality of the education system could not gain quality without transforming teachers. The quality output ${ }^{19}$ in education, input and process should also have quality in terms of efficiency, effectiveness, excellence, and social justice. The quality education output can be achieved only if quality is ensured at each level of the educational process from standard setting, learning environment, teacher training, teacher-learning process, assessment and monitoring.

This study evaluated the institutional problems faced by HSTs with reference to onsite management that diminish the quality process of education. The study covered teachers' job satisfaction, academic facilitation \& environment, managerial treatment and interest etc.

\section{Methods and Procedure of the Study}

The review of related literature about the institutional problems led to construct the questionnaire for collection of the relevant data from the respondents. The target population of the study was 711 High School Teachers (HSTs) working in public secondary schools of SED Sindh, deployed at Mirpurkhas district. The sample was drawn by simple random sampling technique i-e $20 \%$ of the target population was selected from all the 85 public sector secondary schools of Mirpurkhas district ${ }^{20}$. The sample of the study comprised of 126 HSTs with equal number of male and female teachers. The questionnaire constructed for this quantitative study, utilizing survey approach consisted of two parts. The part A consisted of 12 closed ended questions made on 5-point Likert scale and part $B$ consisted of an open question. The questionnaire covered various aspects related with teachers' satisfaction, treatment, facilitation and other institutional problems affecting the quality of input. The data was collected by personal visits of the schools. Descriptive and inferential statistics in terms of percentages and means scores was used to analyze and interpret the data.

\section{Results and Analysis}

The five point, Likert scale questionnaire consisted of 12 closed form and an open question, which are analyzed as under:-

Table 1 shows that $64 \%$ of the respondents agreed that they needed training and 25\% disagreed while $10 \%$ remained undecided. The mean score was 3.3. A good majority of teachers required training; it means that existing training was no more effective. The teachers not only required refresher courses but also the revision of basic training of teaching methodology.

Table 1. Teachers Training

\begin{tabular}{|c|c|c|c|c|c|c|}
\hline SA & A & UD & DA & SDA & Mean & N \\
\hline 06 & 75 & 13 & 28 & 05 & \multirow{2}{*}{3.3} & \multirow{2}{*}{126} \\
\hline 4.8 & 59.5 & 10 & 22 & 3.2 & & \\
\hline
\end{tabular}


Table 2 shows that $76 \%$ of the respondents agreed that teachers lost confidence because of strict actions and media trial against them and $18 \%$ disagreed while $5.6 \%$ remained undecided. The mean score was 3.5. A high majority of teachers considered strict disciplinary actions and media trail responsible for the lost confidence of teachers, although they worked hard and remained devoted to their job.

Table 2. Teachers' confidence

\begin{tabular}{|c|c|c|c|c|c|c|}
\hline SA & A & UD & DA & SDA & Mean & N \\
\hline 07 & 89 & 07 & 19 & 05 & \multirow{2}{*}{3.5} & \multirow{2}{*}{126} \\
\hline 5.6 & 70.6 & 5.6 & 15 & 3.2 & & \\
\hline
\end{tabular}

Table 3 shows that $82 \%$ of the respondents disagreed with the statement that the academic and general facilities at their school were satisfactory and $13 \%$ agreed, while $5.6 \%$ remained undecided. The teaching learning process requires academic facilities as well as general facilities to run smoothly. A high majority reported missing academic and general facilities at the secondary schools which may be a crucial point.

Table 3. The academic and general facilities

\begin{tabular}{|c|c|c|c|c|c|c|}
\hline SA & A & UD & DA & SDA & Mean & N \\
\cline { 1 - 5 } 02 & 14 & 07 & 95 & 08 & \multirow{2}{*}{3.7} & \multirow{2}{*}{126} \\
\hline 1.6 & 11.1 & 5.6 & 75 & 6.3 & & \\
\hline
\end{tabular}

Table 4 shows that $63 \%$ of the respondents agreed that teachers passed time chattering in the staff room and $33 \%$ disagreed while there was no undecided case. The mean score was 3.3. The majority of teachers remained busy in irrelevant talks during school time, although the break time and small intervals were to refresh minds and prepare for next classes.

Table 4. Chattering in staff room

\begin{tabular}{|c|c|c|c|c|c|c|}
\hline SA & A & UD & DA & SDA & Mean & N \\
\hline 11 & 73 & 00 & 30 & 12 & \multirow{2}{*}{3.3} & \multirow{2}{*}{126} \\
\hline 8.7 & 57.9 & 00 & 24 & 9.5 & & \\
\hline
\end{tabular}

Table 5 shows that $74 \%$ of the respondents did not observe educational seminars, discussions or award ceremony in their schools and $16 \%$ agreed while $10 \%$ remained undecided. The mean score was 3.6.

Table 5. Educational seminars

\begin{tabular}{|c|c|c|c|c|c|c|}
\hline SA & A & UD & DA & SDA & Mean & N \\
\cline { 1 - 5 } 01 & 19 & 13 & 85 & 08 & \multirow{2}{*}{3.6} & \multirow{2}{*}{126} \\
\hline 0.8 & 15.1 & 10 & 67 & 6.3 & & \\
\hline
\end{tabular}

A high majority of the respondents reported no seminar or other educational activity for promotion of teaching learning process or appreciation of teachers, if the undecided cases are counted with this report it makes nearly the whole system. This shows the miss interest of the HMs.

Table 6 shows that $65 \%$ of the respondents considered the current format science curricula inadequate and $33 \%$ disagreed with the statement while $2.4 \%$ remained undecided. The means score was 3.3. Analysis of the data shows that majority of the teachers consider the format of elementary science curricula inadequate. The teachers thought that it does not match with the existing facilities situation in the schools.

Table 6. Curricula format

\begin{tabular}{|c|c|c|c|c|c|c|}
\hline SA & A & UD & DA & SDA & Mean & N \\
\hline 11 & 31 & 03 & 35 & 06 & \multirow{2}{*}{3.3} & \multirow{2}{*}{126} \\
\cline { 1 - 5 } 8.7 & 56.3 & 2.4 & 28 & 4.8 & & \\
\hline
\end{tabular}

Table 7 shows that $79 \%$ of the respondents agreed that the solution of teachers' financial and managerial problems lies in the union and $20 \%$ disagreed while $1.6 \%$ remained undecided. The mean score was 3.6. The high majority of teachers have no hope for solution of their problems in the absence of their political unions; therefore, they thought it necessary to participate in teacher's unions.

Table 7. Teachers' Politics

\begin{tabular}{|c|c|c|c|c|c|c|}
\hline SA & A & UD & DA & SDA & Mean & N \\
\cline { 1 - 5 } 03 & 88 & 02 & 13 & 02 & \multirow{2}{*}{3.6} & \multirow{2}{*}{126} \\
\cline { 1 - 5 } 8.7 & 69.8 & 1.6 & 18 & 1.6 & & \\
\hline
\end{tabular}

Table 8 shows that $73 \%$ of the respondents agreed that the treatment of HMs with teachers was not satisfactory and $23 \%$ disagreed while $4 \%$ remained undecided. The mean score was 3.5. A high majority considers HMs behaviour unsatisfactory. They expected professional treatment of HMs with teachers but found negative one.

Table 8. The HMs treatment

\begin{tabular}{|c|c|c|c|c|c|c|}
\hline SA & A & UD & DA & SDA & Mean & N \\
\hline 11 & 81 & 05 & 26 & 03 & \multirow{2}{*}{3.5} & \multirow{2}{*}{126} \\
\hline 8.7 & 64.3 & 04 & 21 & 2.4 & & \\
\hline
\end{tabular}

Table 9 shows that $58 \%$ of the respondents agreed with the statement that the HMs take less interest in academic activities and 37\% disagreed while 5.6\% remained undecided. The mean score was 3.3. Majority of teach- 
ers thought that HMs did not involve themselves in the academic activities which make more than half of the schools. Most of the activities were arranged by the teachers and HMs seemed uninterested.

Table 9. HMs involvement in academic activities

\begin{tabular}{|c|c|c|c|c|c|c|}
\hline SA & A & UD & DA & SDA & Mean & N \\
\cline { 1 - 5 } 06 & 67 & 07 & 43 & 03 & \multirow{2}{*}{3.3} & \multirow{2}{*}{126} \\
\cline { 1 - 5 } 4.8 & 53.5 & 5.6 & 34 & 2.4 & & \\
\hline
\end{tabular}

Table 10 shows that $51 \%$ of the respondents agreed with the statement that the management had satisfactory control on attendance and behaviour of students and $43 \%$ disagreed while $7.9 \%$ remained undecided. The mean score was 3.0. Analysis of the data shows that a slight majority of the teachers thought satisfactory control of management on the attendance and behaviour of students but the other cases considering unsatisfactory control come to half in size if the undecided cases are added with unsatisfactory control.

Table 10. The control of management

\begin{tabular}{|c|c|c|c|c|c|c|}
\hline SA & A & UD & DA & SDA & Mean & N \\
\cline { 1 - 5 } 09 & 55 & 10 & 45 & 07 & \multirow{2}{*}{3.0} & \multirow{2}{*}{126} \\
\cline { 1 - 5 } 7.1 & 43.7 & 7.9 & 36 & 5.6 & & \\
\hline
\end{tabular}

Table 11 shows that $52 \%$ of the respondents disagreed with the statement that the HMs seemed incompetent in managerial affairs and $43 \%$ agreed while $5.6 \%$ remained undecided. The mean score was 3.0. Although a little majority considered HMs competent in managerial skills but the size of other side also comes near to fifty percent if the undecided cases are added with agreed. This is crucial point that teachers considered their HMs incompetent.

\section{Table 11. HMs managerial skills}

\begin{tabular}{|c|c|c|c|c|c|c|}
\hline SA & A & UD & DA & SDA & Mean & N \\
\hline 05 & 49 & 07 & 58 & 07 & \multirow{2}{*}{3.0} & \multirow{2}{*}{126} \\
\hline 04 & 39 & 5.6 & 46 & 5.6 & & \\
\hline
\end{tabular}

Table 12 shows that $65 \%$ of the respondents agreed with the statement that the management was responsible for declining trend in quality of education and $27 \%$ disagreed while $7.9 \%$ remained undecided. The mean score was 3.4. A good majority of teachers considered their HMs and other management responsible for declining trend in quality of education. The quality of education may be gained by team work but here the gap between management and staff is clear.

\section{Table 12. Declining trend in quality of education}

The management is responsible for declining trend in quality of education.

\begin{tabular}{|c|c|c|c|c|c|c|}
\hline SA & A & UD & DA & SDA & Mean & N \\
\hline 11 & 71 & 10 & 31 & 03 & 3.4 & 126 \\
\hline 8.7 & 56.3 & 7.9 & 25 & 2.4 & & \\
\hline
\end{tabular}

Part II

What are the other problems you think that affect the quality input at your school? (Open question)

In this section, $68 \%$ of the respondents reported that the teachers were not promoted on time, $53 \%$ of the teachers reported that there was no library and teaching aids in the school for teachers and $59 \%$ of the teachers pointed out that the status of education at primary level was very low and they had to work very hard.

\section{Discussion and Conclusion}

The education system of Pakistan has not been successful in providing world class education. The lacks of SE system of Pakistan include appropriate infrastructure, skilful ma power, educational resources, environment, preferences and social cooperation.

The teachers felt that they needed professional training. Teachers are appointed trained but the basic teacher's training i.e., B.Ed. has proved timed-out. The teachers required refresher courses to learn new syllabi as well as repetition of teaching skills. The untrained and under qualified teachers appointed in last decades lacked commitment and professionalism. Such teachers remained unwilling to enhance their capabilities and professional expertise. The refresher courses may train them and make professional teachers. But, the system of inservice training also proved useless. The master trainers for in-service trainers may be appointed on favouritism, nepotism or cronyism. Hence, some teachers got such trainings again and again and others remained ignored. The quality of teachers' certification programs suffers from lack of adequately trained master trainers ${ }^{21}$. The teachers lost confidence because of media trails and strict action against them. The department needed to own their employees, the strict actions on unverified news and issues made them very careful hence, lost confidence in dealing with students. It affected the class room management and extra interest of the teachers. 
The schools lack general and academic facilities like libraries, laboratories and power generators. The teachers needed libraries to refer the books for their lesson planning and laboratories for practical work. The majority $65 \%$ of secondary schools did not have libraries ${ }^{22}$, laboratories or equipment and wash room. The schools run like birds without wings in absence of such facilities.

The teachers remained busy in chattering in the staff room which disturbed the involvement in teaching. The gossip continued in schools in the absence of libraries and other academic activities.

The UK Government banned on staff rooms because it caused grouping and aliening which caused grievances ${ }^{23}$. The teachers' gossips are always harmful for the whole system. The staff room discussions about current affairs, political issues, and personal affairs, opposite sex, sect, race or even international politics inhibit the teacher's minds to concentrate on their subjects of teaching. This practice also makes hurdle in lesson planning and preparation for class room teachings. These discussions result grouping, vulgarity and ignorance of teacher's status.

The schools lack educational activities like seminars, discussions or awards for teachers. There were insufficient steps taken by gross root level management to involve the teaching staff and co-curricular activities or their appreciation which make the school environment irrelevant. The teachers considered the format of elementary science curricula inadequate in the absence of required teaching aids, laboratories and equipment. The curricula being taught seems uninteresting and ineffective and out dated ${ }^{24}$. The science books are full of activities, lack content on such topics. Some courses are written in easy languages and other in hard one. Only $9 \%$ of secondary teachers are science qualified ${ }^{25}$. Hence, teaching such curricula affected the input quality of teaching.

A good majority of the teachers set primary education status responsible for low quality of education. The status of primary education is very low that $42 \%$ of the class $\mathrm{v}$ students could read story in mother tongue Urdu or Sindhi and 25\% could read English sentences in rural Sindh ${ }^{26}$. The secondary teachers had to teach them the basic language practices and then teach further. The teachers thought that their involvement in teachers' politics was necessary for solution of their financial and official problems. They felt themselves helpless in the absence of unions. Such unions solved their problems at their doorsteps and created confidence and satisfaction in teachers. Although, such unions also made the base of favouritism, nepotism and cronyism in different matters and affected the school environment but organised in the reaction of treatment of management.

The teachers complained that the HMs treatment with teachers was not professional. The nonprofessional treatment includes decisions with a high hand and use of harsh words for staff. The HMs involvement in academics was found unsatisfactory. They needed to supervise the whole academic process but they confined themselves in compiling information and financial matters.

The management lost control on students' attendance and their behaviour. Such problems create because of reluctance of the management. The poor management of SED was responsible and hindrance in implementing the policies up to grass root level ${ }^{27}$. The teachers thought HMs incompetent in managing the schools: lacked managerial skills, interest and remained isolated. The school temperament depends upon the actions and treatment of the immediate boss. The HM being an educational leader is not expected to ignore any aspect of school administration. They lost confidence following the devolution plan, after which distribution of responsibility and authority was not made clear.

The reluctance of Head masters affects on teaching learning process, the co-curricular activities are witnessed and education becomes uninteresting. The teachers thought HMs responsible for declining trend in education. The management is mostly untrained, only financial matters are taught to the HMs and lack ability to handle day to day issues. The bureaucratic approach was used to run the schools which were not helpful in getting better results from teachers.

The environment of the school also matters in maintaining quality of education. Its responsibility of local management to provide uninterrupted teaching learning process but continues interruption of management, visitors, beggars is observed. Hence, the students as well as teachers lost their concentration again and again. The late promotions created dissatisfaction among teachers. The SED seldom promoted to the HSTs in higher grades hence they lost the will to teach with zeal and zest.

After the analysis of the data obtained, the researcher was able to conclude that the lacks of SE system were need of professional training, losing confidence because of strict actions and media trial, lack of general and academic facilities, teachers' gossip, unsuitable staff room environment, lack of seminars, discussions, libraries , laboratories \& awards, irrelevant curricula format, low 
status of primary education, poor management, lack of managerial skills in HMs and late promotions in Sindh that decline the input quality of education.

\section{Recommendations}

The study recommends a short training course for teachers, appreciation of the work, provision of general and academic facilities in the schools, avoiding gossips by dispersal, arranging educational seminars \& discussions, establishing or equipping libraries and laboratories in schools, giving best teacher awards, converting curricula in easy format, improving quality of primary education, timely promotions of the HSTs, active management and professional training to HMs for better curricular and administrative aspects.

\section{References}

1. Ball DL. Prospective elementary and secondary teachers' understanding of division. Journal of Research in Mathematics Education. 1990; 21;132-44. https://doi. org $/ 10.2307 / 749140$

2. National Policy on Education [Internet]. [cited 2019 Apr 02]. Available from: https://en.wikipedia.org/wiki/ National_Policy_on_Education.

3. Zafar M. Fiscal devolution in education: Case study reflecting initial responses. Ministry of education; 2003. p. 34-41.

4. Pakistan Education Statistics 2015-16 [Internet]. [cited 2017 Feb 28]. Available from: https://reliefweb.int/report/ pakistan/pakistan-education-statistics-2015-16.

5. Shami A. Development of education in Pakistan. Academy of Educational Planning and Management. Ministry of Education; 2005. p. 8-88.

6. Chaudhari P. Secondary Education in India: Issues and Concerns. International Journal of Social Science and Humanities Research. 2016; 4(1):300-5.

7. Highlights: Pakistan Economic Survey 2017-18 [Internet]. [cited 2018 Apr 27]. Available from: https://www.brecorder. com/2018/04/27/414437/highlights-of-pakistan-economic-survey-2017-18/.

8. Malik R. The system of education in Pakistan. National Book Foundation; 2000. p. 1-43.

9. Factors influencing teacher's performance and retention [Internet]. [cited 2015 Jan]. Available from: https:// www.researchgate.net/publication/271721909_Factors_ Influencing_Teachers'_Performance_and_Retention.
10. Ahmed. Critical analysis of education in Pakistan: possible solutions. International Journal of Evaluation and Research in Education. 2014; 2(2):79-84. https://doi.org/10.11591/ ijere.v3i2.1805

11. Fayyaz H. Major issues of education sector in Pakistan. International Journal of Academic Research in Progressive Education and Development. 2014; 3(4):361-76. https:// doi.org/10.6007/IJARPED/v3-i4/1366

12. Park JH, Jeong DW. School reforms, principal leadership, and teacher resistance: Evidence from Korea. Asia Pacific Journal of education. 2013; 33(1):34-52. https://doi.org/10. 1080/02188791.2012.756392

13. Identification of the problems faced by secondary school teachers in Kohat Division, Pakistan [Internet]. [cited 2012 Nov]. Available from: https://www.researchgate.net/ publication/276025541_Identification_of_the_Problems_ Faced_by_Secondary_School_Teachers_in_Kohat_ Division_Pakistan.

14. Critical analysis of problems of school teachers in Pakistan: Challenges and possible solutions [Internet]. [cited 2013]. Available from: https://www.iiste.org/Journals/index.php/ JEP/article/view/4532.

15. Quality school education in Pakistan: Challenges, successes and strategies [Internet]. [cited2011 Jan]. Available from: https://www.researchgate.net/publication/258047276_ QUALITY_SCHOOL_EDUCATION_IN_PAKISTAN_ CHALLENGES_SUCCESSES_AND_STRATEGIES.

16. Sindh education management information system [Internet]. [cited 2017]. Available from: file:///C:/Users/a/ Downloads/Sindhi+hariduse+haldamise+infos\%C3\%BCst eemi+anal\%C3\%BC\%C3\%BCs.pdf. Date accessed:

17. Causes of decline of education in Pakistan and its remedies [Internet]. [cited 2010 Aug 01]. Available from: https:// clutejournals.com/index.php/TLC/article/view/139.

18. Memon GR. Education in Pakistan: The key issues, problems and the new challenges. Journal of Management and Social Sciences. 2007; 3(1):47-55.

19. Quality Primary Education in Pakistan [Internet]. [cited 2016 Dec 27]. Available from: https://atlascorps.org/ quality-of-primary-education-in-pakistans-rural-areasresults-from-annual-status-of-education-report-aser/.

20. Research design: Qualitative, quantitative and mixed methods approaches [Internet]. [cited 2003]. Available from: file:///C:/ Users/a/Downloads/[Creswell,_J.]_Research_design_ Qualitative,_Quant(b-ok.xyz)\%20FOURTH\%20ED.pdf.

21. Arshad M, Qamar AZ, Gulzar HF. Effects of physical facilities at public schools on students' achievement in Punjab, Pakistan. Global Social Sciences Review. 2018; 3(4):102-13. https://doi.org/10.31703/gssr.2018(III-IV).07 
22. Minimum standards for quality education in Pakistan: Attaining standards for improved learning outcomes and school outcome [Internet]. [cited 2013]. Available from: http://planipolis.iiep.unesco.org/en/2016/minimumstandards-quality-education-pakistan-attaining-standards-improved-learning-outcomes-and.

23. Why teachers need a staff room [Internet]. [cited 2012 Apr 09]. Available from: https://www.theguardian.com/ education/shortcuts/2012/apr/09/why-teachers-need-astaff-room.

24. Ahmad G, Arshad M, Qamar AZ, Gulzar HF. Influence of school environment on students outcomes at secondary level. American Based Research Journal. 2018; 7(12):16-23.
25. Ministry of Education [Internet]. [cited 2019]. Available from: http://moe.gov.tt/.

26. Annual Status of Education Report: ASER-Pakistan 2018 [Internet]. [cited 2019]. Available from: https:// learningportal.iiep.unesco.org/en/library/annual-statusof-education-report-aser-pakistan-2018-national.

27. Experts blame poor management for Sindh's education woes [Internet]. [cited 2015 Jan 24]. Available from: https:// www.thenews.com.pk/print/20139-experts-blame-poormanagement-for-sindhs-education-woes. 